\title{
THE VALUE OF THE COMPLEMENT FIXATION TEST IN THE DIAGNOSIS OF MEASLES
}

\author{
J. M. H. BuCKLER, B.M., M.R.C.P., D.C.H. \\ Medical Registrar, Hither Green Hospital
}

\author{
E. H. Brown, D.M., M.R.C.P., D.C.H. \\ Consultant Physician, Hither Green Hospital
}

\author{
J. S. Winchester, M.B., Ch.B.
}

Joan R. Davies, M.D., Dip. Bact.

of the Bacteriological Laboratory (P.H.L.S.) County Hall, London.
DURING the recent (1965) epidemic of measles, the opportunity was taken of evaluating the complement fixation test (CFT) as a means of confirming the diagnosis of measles. The patients were admitted to the hospital during the period December 1964 to Maroh 1965 with a clinical diagnosis of measles. This does not reprosent a true cross-section of the population as admission was requested in most cases either on account of complications (commoner in the younger children) or because of social circumstances e.g. living in Rest Centres, Residential Nurseries, etc.

The complement fixation test was chosen because it was felt that this was the most practicable test to carry out in a small routine laboratory. Both the neutralisation test and the haemagglutination inhibition test require the maintenance of a stable virus suspension and à supply of tissue culture tubes or monkey red-cells. They were regarded as technically more laborious to carry out and likely to give less reliable results than the CFT, which was already being used with other virus antigens. It was also felt that, since CF antibodies become detectable at a slightly later stage of the illness than neutralising antibodies (Stokes, Reilly, Buynak aand Hilleman, 1961), we should be more likely to demonstrate a rise in titre using the CF test.

\section{Sources and Methods}

The age distribution of cases in the various groups is shown in Table 1 . The peak incidence of measles was between 1 and 3 years of age and was probably exaggerated by the factors which led to their admission to hospital. There was a smaller secondary rise between 5 and 6 years of age due to increasing contact on starting school.

Group 1: 141 cases were diagnosed clinically as unequivocal measles.

In those cases seen on the 5th day (2nd day of rash) or before, the diagnosis was based on the catarrhal symptoms, presence of Koplik's spots (usually faded by the 2nd day of the rash, leaving a granular mucosa for a further 24 hours) and the characteristic rash. In most cases seen first on the 6 th day (3rd day of rash), the buccal mucosa was almost normal, but the history of contact and the behaviour of the rash made the diagnosis virtually certain.

Group 2: 17 cases-comprised those in which the diagnosis of measles was doubtful.

The difficulty in diagnosis arose (a) when Koplik's spots were not positively identified in the early cases because they were scanty or absent, - and (b) when the rash was sparse or atypical.

Many patients had received antibiotics for symptoms of respiratory tract infection-especially penicillin, and it was difficult in some cases to exclude the possibility of a sensitivity eruption. It is important that the latter diagnosis should not be made lightly. A few of the rashes encountered (especially when sparse) may have been due to other respiratory tract viruses but these are probably not an important source of error. A number of patients admitted to hospital with a diagnosis of measles which was no tenable on clinical grounds were not included in thise group.

Group 3: 12 persons, and Group 4: 30 persons who had definitely had measles in the past.

The former group had had known recent contact with measles (mainly members of the medical and nursing staff), and the latter group were those who considered they had not had recent contact.

\section{Collection of Sera}

The day on which the rash appeared was taken as the 4 th day of illness and all calculations of the day of collection of serum samples were based on this. Pairs of sera were collected from most of the patients in Group 1 and all the patients in Group 2. The first specimen was collected as soon after onset as possible, usually between day 3 and day 5 . The "convalescent" specimen was collected some nine or ten davs later between day 12 and day 14. From 16 children in Group 1 an additional specimen was collected at about the 8th or 9th day. It was not possible to bleed a few patients in Group 1 during the first week of illness. These will be discussed later. Single samples were taken from those in Groups 3 and 4.

\section{The Complement Fixation Test}

The technique was similar to that described by $\mathrm{N}$ Bradstreet and Taylor (1962). The antigen was $\sigma$ obtained from the Standards Laboratory, Oolindale. It was prepared in $\mathrm{HeLa}$ cells using the Edmonston strain of measles virus. It is important that the $\mathbb{D}$ optimum antigen titre be obtained by a chess-board $\stackrel{\infty}{?}$ titration against a human convalescent measles serum. 0 This optimum was found to be 3 - or 4-fold more concentrated than the optimum obtained using a $\mathbb{\mathbb { D }}$ control serum from a hyper-immunised monkey. 
TABLE 1

\begin{tabular}{|c|c|c|c|c|c|c|c|c|c|c|c|c|c|c|c|}
\hline Age & \begin{tabular}{|c|}
$0-6$ \\
mths.
\end{tabular} & $\begin{array}{c}6 \text { mths. } \\
1 \text { yr. }\end{array} \mid$ & $1-2$ & $2-3$ & $3-4$ & $4-5$ & $5-6$ & 6-7 & $7-10$ & $10-20$ & $20-30$ & $30-40$ & $40-50$ & $50+$ & Total \\
\hline $\begin{array}{l}\text { Group I I } \\
\text { (Definite } \\
\text { Measles) }\end{array}$ & $\begin{array}{c}2 \\
\text { (both } \\
5 \text { mths.) } \\
(1.5 \%)\end{array}$ & \begin{tabular}{c|}
14 \\
$(10 \%)$ \\
\end{tabular} & $\begin{array}{c}45 \\
(32 \%) \\
\end{array}$ & $\begin{array}{c}29 \\
(20.5 \%)\end{array}$ & $\begin{array}{c}13 \\
(9 \%) \\
\end{array}$ & $\begin{array}{c}7 \\
(5 \%)\end{array}$ & $\begin{array}{c}21 \\
(15 \%)\end{array}$ & $\begin{array}{c}5 \\
(3.5 \%)\end{array}$ & $\begin{array}{c}2 \\
(1.5 \%)\end{array}$ & 0 & $\begin{array}{c}3 \\
(2 \%) \\
\end{array}$ & 0 & 0 & 0 & 141 \\
\hline $\begin{array}{l}\text { Group II } \\
\text { (Uncertain } \\
\text { Measles) }\end{array}$ & $\begin{array}{c}1 \\
(4 \mathrm{mths} .) \\
(6 \%)\end{array}$ & $\begin{array}{c}4 \\
(23.5 \%)\end{array}$ & $\begin{array}{c}6 \\
(35 \%) \\
\end{array}$ & \begin{tabular}{c|}
2 \\
$(12 \%)$ \\
\end{tabular} & 0 & 0 & 0 & $\begin{array}{c}1 \\
(6 \%) \\
\end{array}$ & 0 & $\begin{array}{c}1 \\
(6 \%) \\
\end{array}$ & $\begin{array}{c}2 \\
(12 \%)\end{array}$ & 0 & 0 & 0 & 17 \\
\hline $\begin{array}{l}\text { Group III } \\
\text { (Previous } \\
\text { Measles \& } \\
\text { Recent } \\
\text { Contact) }\end{array}$ & 0 & 0 & 0 & 0 & 0 & 0 & 0 & 0 & 0 & 0 & $\begin{array}{c}7 \\
(58 \%)\end{array}$ & $\begin{array}{c}1 \\
(8 \%)\end{array}$ & $\begin{array}{c}2 \\
(17 \%)\end{array}$ & $\begin{array}{c}2 \\
(17 \%)\end{array}$ & 12 \\
\hline $\begin{array}{l}\text { Group IV } \\
\text { (Previous } \\
\text { Measles. } \\
\text { No Recent } \\
\text { Contact) }\end{array}$ & 0 & 0 & 0 & \begin{tabular}{|c|} 
\\
$(3.5 \%)$ \\
\end{tabular} & $\begin{array}{c}1 \\
(3.5 \%) \\
\end{array}$ & 0 & $\begin{array}{c}1 \\
(3.5 \%)\end{array}$ & $\begin{array}{c}2 \\
(7 \%) \\
\end{array}$ & $\begin{array}{c}4 \\
(13 \%) \\
\end{array}$ & \begin{tabular}{c|}
11 \\
$(36.5 \%)$ \\
\end{tabular} & $\begin{array}{c}3 \\
(10 \%) \\
\end{array}$ & 0 & $\begin{array}{c}2 \\
(7 \%)\end{array}$ & $\mid \begin{array}{c}5 \\
(16.5 \%)\end{array}$ & 30 \\
\hline
\end{tabular}

Two and a quarter units of complement and overnight fixation at $+4^{\circ} \mathrm{C}$ were used.

Since an $8 \times 10$ well WHO pattern agglutination tray was used for the tests it was convenient to test the sera in doubling dilutions over the range $1 / 8$ to $1 / 512$ initial serum dilution. In most instances this provided all the information required, occasionally when the first serum was collected late and contained high titre antibodies the range was extended but it was seldom possible to demonstrate a rising titre in this way.

\section{Results}

\section{Group 1. Unequivocal measles}

From 113 patients the first serum was collected before the seventh day of illness; all of them showed a four-fold or greater rise in antibody titre when the second serum was collected after the tenth day of illness. In 90 $(80 \%)$ of these patients the initial titre was $1 / 8$ or less and the titre of the convalescent serum was $1 / 512$ or more. From 15 patients the first serum was not collected during the first week of illness. In seven of these a significant rise in titre could be demonstrated, the remaining eight had high titres $(>1 / 256)$ in the first serum. From 13 patients only a single specimen of serum was obtained 8-19 days after onset. All of them had titres of $1 / 128$ or more.

The distribution of antibody titres at various times after onset of illness is shown in Table 2 and the mean titres in Fig. 1.

It will be seen that most patients had no detectable antibody during the first week of illness. This was interesting in view of the fact that although the onset of the rash most commonly occurs on the fourth day of illness the prodromal symptoms may be as long as seven days (or as short as two days). By the eighth or ninth day the antibody titre was rising, rapidly in most cases, so that by the tenth day no titre of less than $1 / 128$ was observed.

\section{Group 2. Doubtful measles}

Four of the 17 cases showed clear cut rising titres of antibody similar to those observed in Group 1. Of the remainder, eight had no detectable antibody and five had stationary titres $(1 / 8,1 / 8,1 / 32,1 / 128,1 / 256)$.

\section{Groups 3 and 4. Persons with a past history of measles}

Almost all the sera examined contained detectable CF antibody often at a high level as shown in Fig. 2. These findings confirm those of other workers (Black, 1959; Bech, 1960) that the antibodies produced after an attack of measles in childhood persist for life, but presumably are boosted from time to time by reinfection. All of these sera were collected during a measles epidemic so that the differentiation of those with known recent contact (i.e. members of the staff) from the rest may not be valid. Unfortunately, the age range of Group 3 was rather limited, and predominantly different from those without contact. Apart from Groups 3 and 4 two sera were examined from adults who thought they had not had measles. Both of them had antibody (1/16 
TABLE 2

Distribution of Antibody Titres at Various Times after OnSEt of Illness.

\begin{tabular}{|c|c|c|c|c|c|c|c|c|c|c|}
\hline \multirow{2}{*}{$\begin{array}{l}\text { Day of } \\
\text { Illness }\end{array}$} & \multicolumn{10}{|c|}{ Reciprocal C.F. Titres } \\
\hline & $<8$ & 8 & 16 & 32 & 64 & 128 & 256 & 512 & $>512$ & Total \\
\hline $1-6$ & $\underbrace{91}$ & $\underbrace{14}_{94 \%}$ & $\jmath^{2}$ & 0 & $\underbrace{3}_{4 \%}$ & 1 & ${ }^{2}$ & $\underbrace{0}_{2 \%}$ & 0 & 113 \\
\hline $7-10$ & 6 & $\underbrace{2}_{31 \%}$ & 1 & 0 & $\underbrace{1}_{21 \%}$ & 5 & 5 & $\underbrace{2}_{48 \%}$ & 7 & 29 \\
\hline$>10$ & 0 & $\underbrace{0}_{0 \%}$ & ر & 0 & $\underbrace{0}_{3 \%}$ & 4 & $1 \underbrace{15}$ & $\underbrace{14}_{97 \%}$ & $j^{10}$ & 143 \\
\hline
\end{tabular}

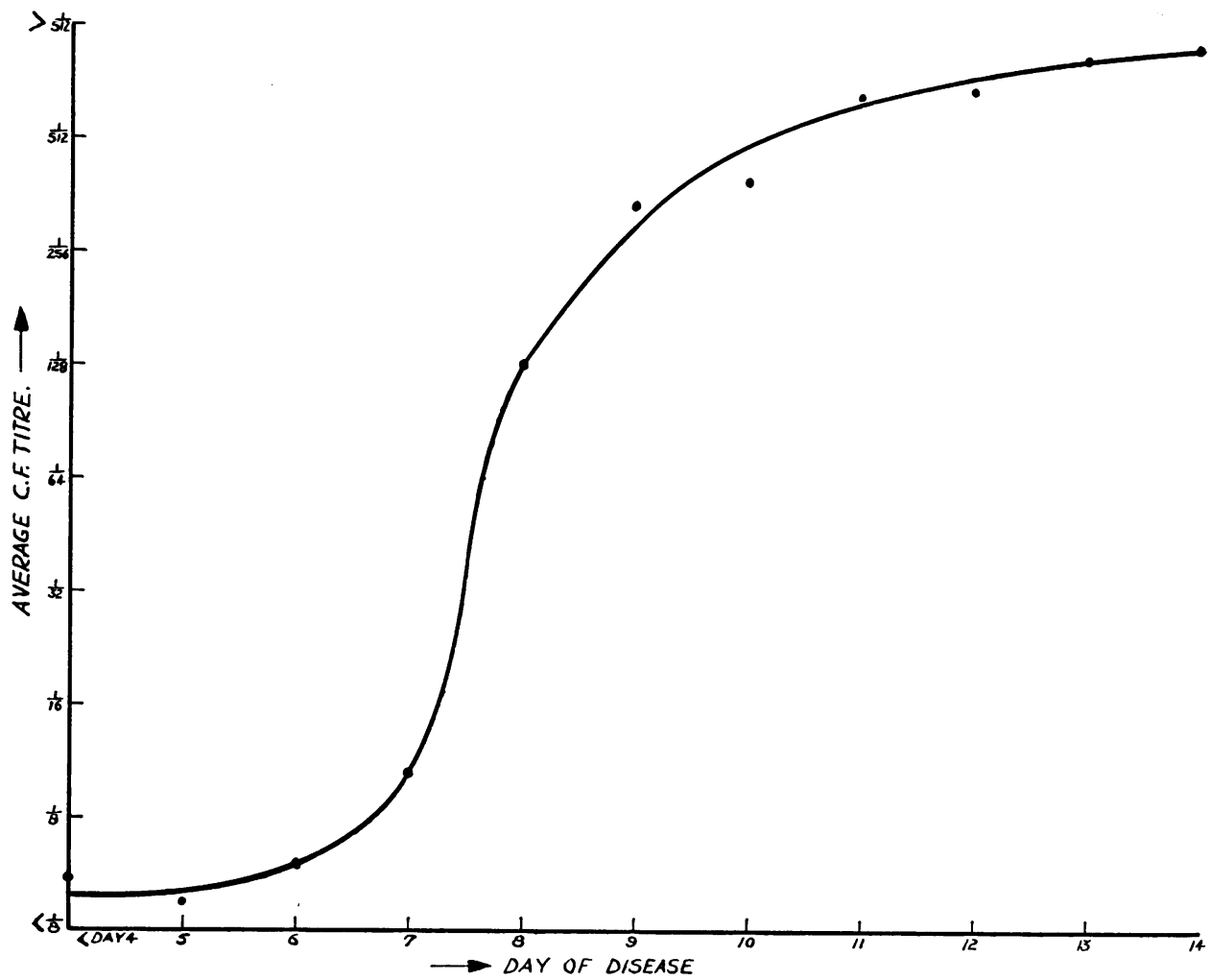

FIG. 1.-Average C.F. titre on various days of disease. 


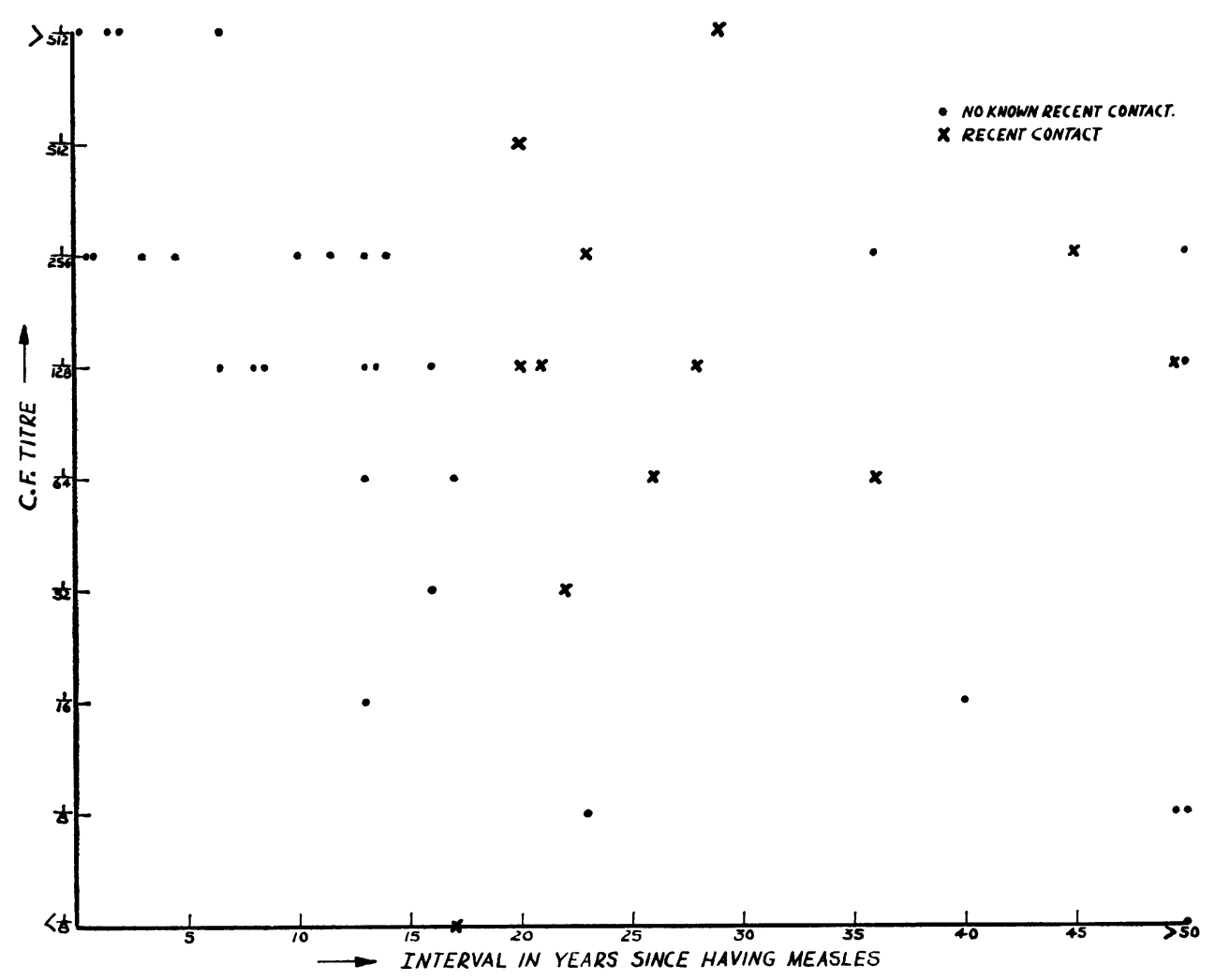

FIG. 2.-C.F. titre levels in population having previously had measles.

and $1 / 256)$ and probably had, in fact, acquired the infection at some stage.

\section{Discussion}

The results described here confirm the value of the oomplement fixation test in the diagnosis of measles. Provided that a pair of sera was examined, the first specimen being collected during the first week of illness and the second after the tenth day, a significant rise in antibody titre could always be demonstrated. The presence of antibody, even in very high titre, in a specimen of serum collected more than a week after onset of illness cannot be interpreted since although it is consistent with recent measles, it may merely be evidence of past infection.

The observation on persons who had had measles in the past show the high titres of antibody which may be expected, particularly in those who are repeatedly exposed to infection. There are oircumstances in which it is important to make a certain diagnosis of measles. This can only be done clinically if Koplik's spots are identified, and is only possible in the period two to three days before the rash and about 24 hours afterwards. In many cases, however, at that stage, Koplik's spots may be scanty, but for experienced clinicians a clinical diagnosis in this early phase of the disease is as reliable as any serological tests - except in those patients where the disease is modified by passive immunity from the mother (from the fifth to eighth month of life) or if attenuation has resulted from gammaglobulin. After the sixth day, although the behaviour of the rash may be compatible with measles, a certain diagnosis is not possible on clinical grounds. Antibiotics are given all too frequently without clear indication in upper respiratory tract infections and sensitivity eruptions are becoming more frequent.

The problem in the future may be the diagnosis of measles in those who have received measles vaccine. If this comes into general use, a confident diagnosis of measles will be 
important, if we are to assess the efficacy of the vaccine. In a case modified by immunisation (whether live attenuated vaccine alone, or killed followed by live vaccine) both clinical manifestations and serological response may be altered, and it remains to be seen whether it will then be possible to demonstrate a significant rise in antibody titre.

We had the opportunity of examining sera from six children who had had measles vaccine. Three were bled after one month and had titres of $1 / 256$ to $1 / 512$. The other three had received the vaccine five to six months previously. One of these had a titre of $1 / 256$, another of $1 / 8$ and the third, who has already been mentioned as a case of doubtful measles, had a stationary titre of $1 / 8$. Further experience of vaccinated children will be necessary before the value of serological testing can be assessed.

\section{Summary}

The CFT has been shown to be a reliable test in confirmation of diagnosis of doubtful measles.
High titres tend to persist throughlout life although this may be due to repeated boosting by contact.

A plea is made for the avoidance of indiscriminate use of antibiotics in the treatment of upper respiratory tract infections and for greater care in the clinical diagnosis of measles.

We are indebted to Dr. Patricia Bradstreet of the Standards Laboratory, Colindale, for generous supplies of measles antigen.

\section{REFERENCES}

ВеCH, V. (1960): Titres of Complement Fixing Measles Antibodies in Sera Collected at Random from Healthy Persons in Copenhagen, Acta path. microbiol. scand., 50, 322.

Black, F. L. (1959): Measles Antibodies in the Population of New Haven, Conn., J. Immunol., 83, 74.

Bradstreet, C. M. P., and Taylor, C. E. D. (1962): Technique of Complement Fixation Tests Applicable to the Diagnosis of Virus Diseases, Mon. Bull. Minist. Hlth. Lab. Serv., 21, 96.

Stokes, J., Reilly, C. M., Buynak, E. B., and HillemaN, M. R. (1961): Immunologic Studies of Measles, Amer. J. Hyg., 74, 293. 